\section{Reactor refit ignites debate on Japan's fusion strategy}

Robert Triendl, Tokyo

The Japan Atomic Energy Research Institute (JAERI) plans to overhaul its JT-60 tokamak fusion reactor at a cost of $¥ 35$ billion (US\$325 million). The task will take between five and ten years.

The reactor will be shut down in autumn of next year so that its magnetic coils can be replaced with superconducting ones. According to Masato Nakamura, director of the fusion development office at the Science and Technology Agency, of which JAERI is part, the goal is to increase the reactor's normal operation time from 15 to 100 seconds.

But what looks to be a boost for fusion might actually indicate that budgets for such research are growing tight in Japan, some observers say. The tokamak's closure will save a large part of its $¥ 10$ billion annual operating costs - so the reconstruction could save the government money if it takes long enough. A completion date for the project has not been announced. And the Science and Technology Agency's budget request for 2001 includes only $¥ 2.3$ billion for the reconstruction.

Fusion researchers are far from enthusiastic at the prospect of the reactor being shut down for up to ten years. "In terms of technology, replacing the coils should take three or four years and we hope this is what happens," says Shinzaburo Matsuda, director of JAERI's Naka Fusion Research Establishment.

Nakamura defends the plan, arguing that reconstructing the reactor will make it more economical and stable.

Both Nakamura and Matsuda insist that the plan will not affect Japan's commitment to the proposed International Thermonuclear Experimental Reactor (ITER) project.

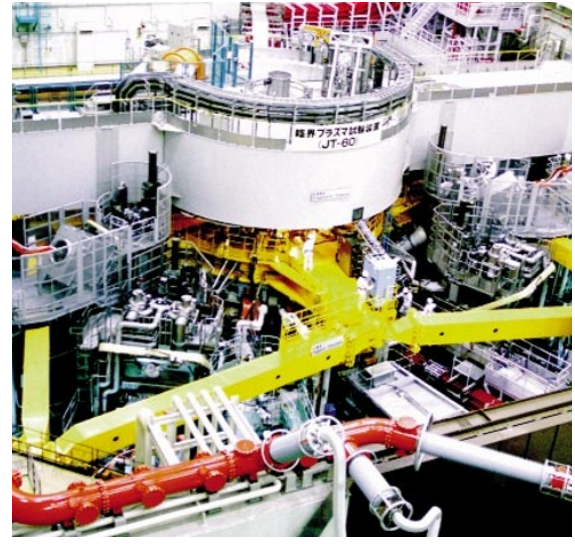

Off line: refurbishment of Japan's JT-60 fusion reactor could take up to ten years.

"We believe that siting ITER in Japan is essential for the project's success," says Nakamura.

According to Nakamura, savings from the suspended operation of JT-60 will make it easier for Japan to increase its contribution to the ITER project.

Matsuda adds that, in its long term plan for fusion research, the Japanese Atomic Energy Comission defined an experimental reactor like ITER as the "core reactor" while designating "other tokamak devices" for advanced research to support the core machine during both the experimental and demonstration phases.

But Steve Dean of Fusion Power Associates, which lobbies for fusion research in Washington, expressed surprise at the plan. Although Japanese officials had said they could do both, outsiders had assumed that Japan would decide either to refurbish JT-60 or to proceed with ITER, he said.

\title{
US lab animals may win in lawsuit
}

Meredith Wadman, Washington

In a stinging defeat for the biomedical research lobby, the United States Department of Agriculture (USDA) is about to settle a lawsuit brought by animal-rights activists which seeks to bring some 23 million laboratory rats, mice and birds under the protection of the Animal Welfare Act.

If the suit is successful, $95 \%$ of laboratory animals will be subject to a new set of federal regulations. On Monday, the USDA was in the final stages of negotiating a settlement under which the agency would begin procedures that might lead to the extension of the law.

Advocates of biomedical research criticized the move. "Settling this suit without taking into account the deep concerns of the research community is a serious mistake," said a statement from Jordan Cohen, the president of the Association of American Medical Colleges.

The lawsuit was filed last year by the Minnesota-based Alternatives Research and Development Foundation, which argued that the agriculture department had "arbitrarily and capriciously" excluded these animals from the 1966 law (see Nature 400, 197-198; 1999).

Researchers argue that other regulations already force them to take appropriate care of rats, mice and birds.
Genomics initiative to decipher 10,000 protein structures

Paul Smaglik, Washington

In a bid to crack protein structures, the US National Institute of General Medical Sciences (NIGMS) last week launched the largest project to date to find the best methods for unravelling the molecules' three-dimensional make-up.

As part of its structural genomics initiative, the institute will provide $\$ 150$ million over five years to seven regionally based research groups. The NIGMS aims to solve the three-dimensional structure of 10,000 proteins - each representing a protein family - over the next decade.

Structural genomics compares how proteins of known structure share functions or gene sequences with unsolved proteins. It then uses computation to predict structures for the unsolved proteins.

But to assemble a full protein library, structural biology's technology and methodology need to improve. To that end, the seven groups will use robotics to automate protein characterization. Some will also seek to expedite or eliminate steps in sample preparation - the biggest bottleneck in large-scale characterization.

Each of the groups is using a different rationale for choosing which proteins to characterize. They will study proteins from different organisms, ranging from yeast to humans. Some will use X-ray crystallography, whereas others will rely on nuclear magnetic resonance spectroscopy to solve the structures. The challenge will be to take advantage of the diversity of approaches while avoiding redundancy, says John Norvell, director of the NIGMS project.

But some duplication of effort is desirable, as similar structures can arise from drastically different genetic sequences. It would also be helpful when groups are trying out new methods for discerning structures.

In addition, redundancy could come in the form of competition from similar projects. For example, Britain's Wellcome Trust is thinking about organizing an industrial structural genomics consortium (see Nature 406, 923; 2000).

But Stephen Burley, a Rockefeller University structural biologist, and one of the seven principal investigators selected by the NIGMS project, says that industrial researchers will be more interested in medically important proteins. The NIGMS project, in contrast, aims for breadth, not depth. http://www.nigms.nih.gov/funding/psi.html 